
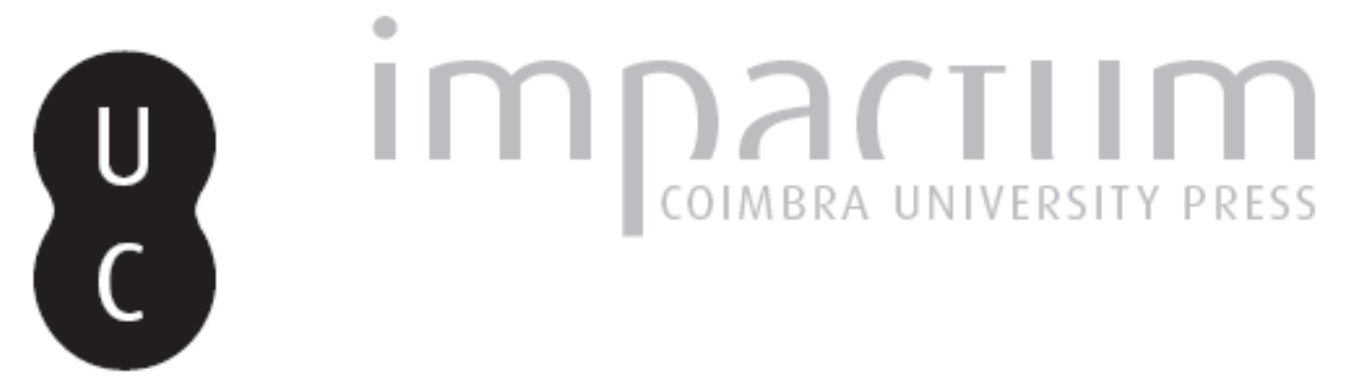

\title{
Relações externas do Egipto no período Saíta
}

Autor(es): $\quad$ Carmo, Filipe Neves do

Publicado por: Centro de História da Universidade de Lisboa

URL persistente:

URI:http://hdl.handle.net/10316.2/23722

DOI:

DOI:http://dx.doi.org/10.14195/0871-9527_20_10

Accessed : $\quad$ 26-Apr-2023 12:59:25

A navegação consulta e descarregamento dos títulos inseridos nas Bibliotecas Digitais UC Digitalis, UC Pombalina e UC Impactum, pressupõem a aceitação plena e sem reservas dos Termos e Condições de Uso destas Bibliotecas Digitais, disponíveis em https://digitalis.uc.pt/pt-pt/termos.

Conforme exposto nos referidos Termos e Condições de Uso, o descarregamento de títulos de acesso restrito requer uma licença válida de autorização devendo o utilizador aceder ao(s) documento(s) a partir de um endereço de IP da instituição detentora da supramencionada licença.

Ao utilizador é apenas permitido o descarregamento para uso pessoal, pelo que o emprego do(s) título(s) descarregado(s) para outro fim, designadamente comercial, carece de autorização do respetivo autor ou editor da obra.

Na medida em que todas as obras da UC Digitalis se encontram protegidas pelo Código do Direito de Autor e Direitos Conexos e demais legislação aplicável, toda a cópia, parcial ou total, deste documento, nos casos em que é legalmente admitida, deverá conter ou fazer-se acompanhar por este aviso.

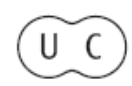




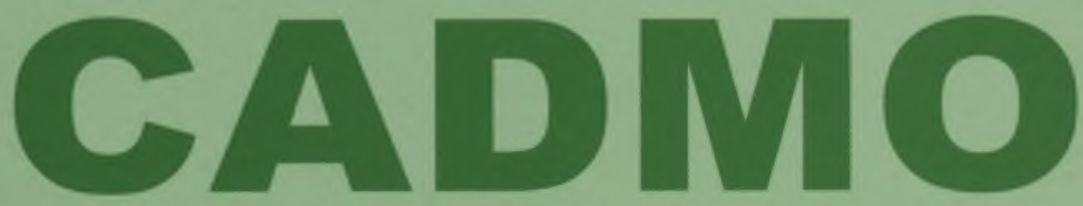

Revista de História Antiga

\author{
Centro de História \\ da Universidade de Lisboa
}

\title{
20
}

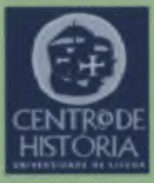

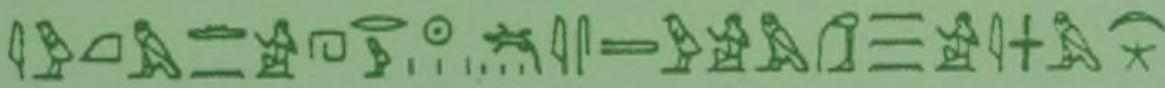

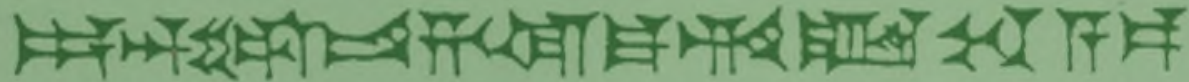

MHNIN AEI $\Delta$ E $\Theta E A ~ \Pi H \Lambda H I A \triangle E \Omega$ 


\section{RELAÇÕES EXTERNAS DO EGIPTO NO PERÍODO SAÍTA}

FILIPE NEVES DO CARMO

Universidade de Lisboa filcarm@gmail.com

O período de decadência que se seguiu à queda do Império Novo teve momentos em que se vislumbrou uma recuperação da grandeza egípcia mas de facto só se pode falar de verdadeiro renascimento com o período saíta. O Terceiro Período Intermediário (1070-664 a. C.), que se poderá caracterizar por uma ausência de centralização do poder que é normalmente associada aos períodos conturbados, só terá de facto terminado, para uma parte considerável dos especialistas, com o reinado de Psametek I (664-610), fundador da XXVI dinastia.

$\mathrm{Na}$ realidade, os faraós núbios, também designados cuchitas, da XXV dinastia terão imposto o seu domínio a todo o Egipto já desde 727 a. C. - primeiro com a incursão vitoriosa de Pié nesse ano e de novo com Chabaka doze anos depois - mas a verdade é que os príncipes líbios instalados no Delta parece, embora derrotados, nunca se terem efectivamente submetido ao novo poder núbio. $O$ reforço do culto de Amon terá sido a principal preocupação dos faraós desta dinastia e o domínio de Mênfis e do Baixo Egipto, designadamente através de uma forte presença em Tebas, o meio privilegiado de exercer tal domínio.

O ano de 671, em que uma invasão assíria conduziu a uma série de derrotas das forças egípcias e à conquista e saque de Mênfis, terá culminado um período de cerca de três ou quatro décadas de relações tensas dos faraós com os soberanos asiáticos. A substitui- 
ção, através de todo o Egipto ocupado, provavelmente até uma área não muito ao sul de Mênfis, dos funcionários e administradores de Taharka, o então faraó, por egípcios favoráveis aos invasores, poderá significar que os príncipes do Delta preferiram na altura um suserano estabelecido em Ninive a um residente em Mênfis. Taharka não se terá, contudo, dado por vencido e, aproveitando a morte de Assaradão, o rei assírio, reconquistou Mênfis e restabeleceu a sua autoridade sobre o país. A reacção do novo rei assírio, Assurbanípal, não se limitou a uma segunda invasão e à reocupação de Mênfis: por um lado, prosseguiu o seu avanço até Tebas obrigando Taharka a refugiar-se na Núbia; por outro, no seu regresso a Ninive, levou consigo um número considerável de prisioneiros, entre os quais se terão encontrado um príncipe de Tebas, muitos príncipes e governadores das cidades do Delta e, em particular, um personagem, Necau, descrito como rei de Mênfis e de Saís ${ }^{(1)}$.

Os príncipes e outros nobres que apoiaram os invasores não demoraram muito tempo a aperceber-se de que a nova suserania também Ihes não agradava e revoltaram-se na primeira ocasião, recorrendo a Taharka. A reacção assíria foi brutal, enviando mais prisioneiros egípcios e núbios para Ninive e exercendo uma cruel vingança sobre os habitantes de algumas das cidades do Delta. De todos os prisioneiros detidos em Ninive apenas Necau foi poupado e reenviado para Saís, aparentemente com alguma delegação do poder. Também o seu filho, o futuro Psametek I, foi objecto de favorecimento similar, tendo-Ihe sido atribuído o principado de Athribis. Oportunamente assumiria o mandato do pai (que terá perecido em 664 a. C., em luta contra Tanutamon, cujo antecessor, Taharka, também terá morrido nesse ano, data que é assumida como o momento de inauguração da nova dinastia e o início do reinado de Psametek) e, não obstante uma nova invasão de Assurbanípal para fazer face a uma tentativa de reconquista por parte de Tanutamon, o novo rei núbio, o seu papel de cliente do suserano assírio foi-se esbatendo com o tempo e o seu poder efectivo aumentando consideravelmente.

O período que precede a XXVI dinastia, o dos faraós kuchitas e mesmo anteriormente, foi fértil em episódios não só de invasões assírias do Egipto mas também de presenças de exércitos egípcios no Levante, normalmente em apoio às cidades locais contra o domínio assírio. $O$ interesse estratégico das duas potências nessa região, de conteúdo claramente económico, terá levado a essas guerras e o que se torna mais difícil de explicar é o facto de os assírios se terem visto 
"obrigados" a invadir o Egipto por várias vezes. De facto(2) a geografia e a incapacidade assíria de dominar as rotas de comunicação por terra e por mar entre os dois países nesse período tornavam o Egipto um país difícil de conquistar, e a seguir, dada também a sua dimensão e complexidade sociocultural, de governar. Por um lado, o acesso por terra ao país do Nilo pressupunha a travessia do deserto do Sinai, o que não era possível sem recorrer às tribos árabes que eram as únicas a controlar o meio de transporte adequado na época, o camelo. Complementarmente era necessário controlar as várias cidades palestinas e sírias que se encontravam no percurso terrestre, o que de facto se verificava mas sofria perturbações com as frequentes revoltas dessas cidades. Por outro lado, o acesso por mar, dado que a Assíria não dispunha de portos de mar nem de marinha própria, exigia a cooperação dos portos da costa levantina, o que em princípio era factível dada a sua incorporação no império, mas estava prejudicado não só pelo seu carácter indirecto mas também pelas revoltas já referidas, que abrangiam igualmente as cidades portuárias.

Estes factores fundamentalmente geográficos não influenciavam unicamente as relações militares e políticas. Também as relações económicas eram seriamente afectadas e, dadas as tensões existentes entre as duas potências, dificilmente iam além dos movimentos unidireccionais de produtos determinados pelo saqueio associado à conquista, pelo tributo derivado das situações de domínio político ou, marginalmente, os gestos de boa vontade constituídos pelas ofertas unilaterais ou recíprocas (dom e contra-dom). É este último tipo de transacção que parece predominar até à primeira conquista do Egipto por Assaradão, período em que os presentes provenientes do Egipto, directamente ou através das cidades fenícias e constantes dos registos assírios, incluem sobretudo animais exóticos ou cavalos em número reduzido(3). Já com a conquista de Assaradão, os registos passam a indicar cavalos em grande número (que os faraós aparentemente importavam da Ásia, ou parcialmente faziam criar no Egipto, e que se destinavam à formação de uma força de carros de guerra), estes já certamente resultantes do saqueio efectuado ou do tributo imposto. Outros produtos do Egipto constam, a partir dessa primeira conquista, dos registos assírios, como tecidos de linho, ouro, algodão, alúmen, natrão, papiro e conservas de peixe, embora não tenha sido possível determinar se as importações resultavam de saqueio, tributo ou comércio regular, e se eram directas ou eram transaccionadas através das cidades fenícias e filistinas ${ }^{(4)}$. 
Neste enquadramento, não custa a entender que Assurbanipal tenha passado a considerar os soberanos núbios (os promotores de facto das interferências egípcias no Levante nas últimas décadas) como o seu verdadeiro inimigo ${ }^{(5)}$ e por isso se terá limitado a estabelecer um acordo de paz com alguns príncipes do Delta, mesmo após o esmagamento da sua revolta. Após várias invasões, terá sido reconduzido a admitir como objectivo fundamental o exercício da sua soberania sobre a costa levantina e as suas cidades mercantis e acessoriamente a procurar impedir que o reino do Nilo prejudicasse tal exercício. O perdão concedido a Necau teria de facto representado, assim, o estabelecimento de uma aliança, o que é consistente com o comportamento posterior deste príncipe e de Psametek, quando da incursão de Tanutamon.

De acordo com Heródoto (II.151), a aquisição de poder por parte de Psametek começou após um exílio nos pântanos do Delta, local onde terá recorrido ao auxílio de piratas cários e jónios ${ }^{(6)}$ com a perspectiva de resistir ou impor-se aos outros príncipes do Baixo Egipto, com os quais se teria incompatibilizado face às posições antagónicas assumidas quando da tentativa falhada de Tanutamon, em que se terá colocado do lado do suserano assírio(7). Este recurso a mercenários gregos ter-se-á revelado indispensável dada a retirada das tropas invasoras assírias (ou a insignificância das guarnições deixadas) após a vitória sobre Tanutamon. A utilização dos mercenários contra os diferentes principados do Delta, quer tenha sido efectiva ou meramente virtual (ameaça de uso da força), ter-se-á estendido por um período relativamente longo (provavelmente sete ou oito anos), no final do qual a suserania de Psametek nessa área terá ficado bem estabelecida. O novo soberano ter-se-á então sentido suficientemente forte para tentar estender o seu domínio ao sul do Egipto.

Toda a habilidade diplomática de Psametek se terá então afirmado, primeiro conseguindo um entendimento com o senhor local de Heracleópolis, provavelmente através de uma aliança conjugal prévia, depois conseguindo fazer adoptar a sua filha Nitocris por Amenirdis II, ela própria filha adoptiva de Chepenupet II, a divina esposa de Amon no pontificado de Tebas. O simbolismo deste acto de adopção, a futura assunção da posição de divina esposa de Amon por parte da sua filha, significava de facto a aceitação por parte das autoridades religiosas e civis de Tebas de Psametek como o suserano do Alto Egipto. Dever-se-á sublinhar que já os reis núbios da XXV dinastia haviam 
recorrido à adopção das suas filhas pela esposa divina de Amon para assegurarem a respectiva sucessão e garantirem assim a sua aceitação como faraós.

De acordo com Heródoto (II.154), após ter utilizado os mercenários cários e jónios contra os seus opositores no Delta, Psametek instalou-os em dois acampamentos situados a norte de Bubástis, no ramo pelusíaco do Nilo. Quer esta instalação fosse motivada por razões de segurança interna quer para controlar a estrada de acesso à Ásia, o certo é que ${ }^{(8)} \mathrm{o}$ agente perturbador em períodos anteriores, os líbios, parece não ter então constituído preocupação suficiente para o novo faraó, o que dá uma ideia do grau de controlo então atingido sobre o país ${ }^{(9)}$. A leste, por outro lado, os Assírios tinham claramente outras preocupações, a falta de iniciativas de Psametek na região levantina tendo provavelmente também contribuído para os manter alheios relativamente aos acontecimentos no reino do Nilo. Ainda de acordo com James ${ }^{(10)}$, pelo menos na fase inicial do reinado deste faraó, terá havido identidade de interesses entre as duas potências, quer devido à subsistência da situação de clientelismo já referida, quer a uma concertação activamente desejada ou meramente derivada da incapacidade de assumirem riscos adicionais em matéria de relações internacionais. Isso teria levado a que o longo reinado de Psametek (54 anos) prosseguisse num ambiente geral de paz interna e externa em que as únicas excepções conhecidas tivessem sido constituídas por uma intervenção na Palestina (cerco e conquista de Asdod, que segundo Heródoto, em II.157, terá durado vinte e nove anos e que visaria o controlo de uma via comercial de ligação à Síria) e um envolvimento ao lado dos assírios, em 616 a. C., contra os babilónios.

Não há contudo unanimidade, por parte dos académicos, quanto a esse ambiente geral de paz e de concertação com os assírios. Segundo alguns autores, que se baseiam sobretudo em fontes assírias, Psametek ter-se-á livrado da vassalagem a Assurbanípal cerca de dez anos depois de ter assumido o poder e para isso terá contado com o apoio dos hoplitas gregos que Gyges, rei da Lídia, Ihe havia enviado(11). Outros autores limitam-se a dizer que o soberano egípcio deixou de enviar tributo a Assurbanípal. Psametek terá, por outro lado, assumido posições ofensivas relativamente a uma parte do domínio reivindicado pelos 
assírios, precisamente a costa levantina, de que é exemplo o acima referido cerco a Asdod (uma cidade situada sobre a grande estrada que ligava Damasco ao Egipto e que era uma posição militar e comercial da maior importância). Terá sido assim que já no final do seu reinado teria subtraído o domínio dessa costa ao rei assírio, nomeadamente no que respeita às cidades fenícias, gabando-se de que os seus funcionários aí exerciam controlo sobre a produção e exportação de madeiras ${ }^{(12)}$. A iniciativa conjunta com os assírios contra os babilónios em 616 a. C. seria assim o resultado de uma aliança entre iguais, através da qual Psametek procurava manter o equilíbrio de poder na Mesopotâmia com o objectivo último de não ver prejudicado o seu domínio (ou o reforço desse domínio) na área levantina ${ }^{(13)}$.

A manutenção, e provavelmente mesmo o reforço, da força de mercenários gregos por Psametek I após a sua vitória sobre os príncipes do Delta, poderá encontrar explicação na oposição a eventuais forças assírias de ocupação na década que se seguiu à sua tomada de poder e mais tarde para o apoiar nas suas iniciativas a leste. Há que não esquecer que as invasões assírias tinham deixado o Egipto extremamente debilitado no que respeita à sua força de carros de guerra (apropriação dos cavalos egípcios por Assarhadão) e que precisamente os contingentes gregos, sendo essencialmente constituídos por infantaria pesada, dispensavam, pelo menos parcialmente, a reconstituição dessa força( ${ }^{(14)}$. A infantaria grega, cuja eficiência haveria de ser historicamente comprovada nos séculos seguintes, apresentava ainda a vantagem de vir completamente equipada com armas e armaduras próprias.

A remuneração dos mercenários, se é que é adequado falar em remuneração e em mercenários, era muito provavelmente constituída apenas pela concessão de terras. O pagamento em moeda, pelo menos em meados do século VII, estaria completamente excluído dado que as emissões egípcias só muito mais tarde é que seriam iniciadas e a aquisição de moeda lídia ou grega (esta última também de duvidosa existência na altura) para o efeito não só não está comprovada arqueologicamente como parece absurdo admitir que um soberano egípcio pudesse então conceber a respectiva utilização. A concessão de terras, diversamente, era o sistema tradicional utilizado pelo Estado egípcio para retribuir a prestação de serviços pela casta guerreira. Por outro lado, adequava-se à situação específica dos camponeses gregos, empurrados para a colonização por uma demografia explosiva ou expulsos das suas terras pelo funcionamento de um sistema económico- 
-social que conduzia a uma apropriação crescente da terra por uma oligarquia latifundiária. De facto, os camponeses gregos, com o seu estatuto de cidadãos e perdendo as suas terras, não aceitavam trabalhar para um senhor - o que era incompatível com tal estatuto e os reduziria à condição de servos - e optavam frequentemente pela partida em busca de outras terras que pudessem trabalhar como suas. Mais do que mercenários eram pois camponeses que procuravam terras.

De novo em 610 Psametek enviou um exército para a Síria com o objectivo de apoiar os assírios contra o nascente Império Neo-babilónio. O seu filho Necau II (610-594) continuou a sua política e logo em 609 travou com sucesso uma batalha na Palestina, na qual o rei de Judá, então aliado da Babilónia, encontrou a morte. O súbito colapso do domínio assírio após 609 terá resultado(15) num sério vazio de poder que ameaçava ser preenchido pelos Babilónios, tendo a intervenção egípcia neste período resultado em vários sucessos, entre os quais a captura de uma cidade a sul de Karkemich com a sua guarnição babilónica e a perseguição de uma força inimiga para lá do Eufrates. James chega aliás a afirmar que, durante alguns anos, Necau terá sido capaz de manter um certo controlo sobre uma parte considerável da Ásia Menor, que se estendia desde o Mediterrâneo até ao Eufrates a norte de Karkemich, e que incluía Judá e talvez mesmo alguns dos antigos estados tributários da Assíria que se encontravam na área. Esta fase de intervenção terrestre no Levante terminou contudo com uma pesada derrota de Necau em Karkemich (605) ${ }^{(16)}$, após o que os soberanos egípcios passaram a privilegiar uma presença marítima na costa levantina, abandonando a Ásia Menor e permitindo a ocupação de toda a região pelos Babilónios. James ${ }^{(17)}$ refere ainda uma tentativa de invasão do Egipto por parte de Nabucodonosor, travada por Necau nas proximidades da fronteira oriental do país, com perdas importantes para os dois lados.

Não é claro que o objectivo inicial de Necau, com a sua nova política de construção de um poder naval, tenha sido o de continuar por outros meios a sua oposição ao império neo-babilónico. Inicialmente o seu esforço virou-se para a construção de um canal entre o Nilo e o golfo de Suez, obra (descrita em Heródoto II.158) que seria interrompida e mais tarde concluída no período persa por Dario I. 
Após essa interrupção adoptou uma política de construção de triremes, que utilizou tanto no Mediterrâneo como no mar Vermelho e que - levaria a lançar uma expedição de circum-navegação do continente africano(18). As expedições a partir do mar Vermelho poderão indicar que Necau procurava alternativas às importações habitualmente asseguradas a partir da Fenícia e não uma continuação por outros meios da luta contra os babilónios. As tripulações utilizadas nos navios terão sido inicialmente fenícias mas a dificuldade no respectivo recrutamento, devida à ocupação neo-babilónica, terá progressivamente forçado Necau a recorrer a gregos ${ }^{(19)}$. O mesmo se terá em princípio passado no que respeita à construção dos navios. Tem-se especulado por outro lado que o objectivo de Necau com a construção do canal entre o Nilo e o golfo de Suez visava controlar o comércio das especiarias e do incenso com o mundo mediterrânico, no qual os comerciantes fenícios teriam um papel fundamental(20).

A existência de uma zona em Mênfis habitada por fenícios e conhecida como o Campo dos Tírios (Heródoto II.112) tem sido interpretada como um indicador de que haveria relações comerciais bem estabelecidas entre o Egipto e Tiro na época de Psametek I - que teria sido quem patrocinou a respectiva instalação - e que as mesmas teriam prosseguido no reinado do seu filho. Corral(21) apresenta Tiro como um aliado estratégico do Egipto no final do século VII, não só em termos comerciais mas também políticos. O controlo das vias comerciais levantinas, tanto terrestres como marítimas, face à ameaça babilónica, teria assim justificado o desenvolvimento da força naval egípcia no Mediterrâneo Oriental. De facto, a hegemonia babilónica foi-se afirmando progressivamente na área (destruição de Ashkelon, Ekron, Gaza, Asdod, Tel Batash-Timnah e outras cidades entre 604 e 600 ), dando prioridade à erradicação da influência egípcia e não à exploração económica destes territórios.

Segundo Vanderhooft, a política babilónica diferiu radicalmente da do seu antecessor assírio, que procurava estimular o desenvolvimento económico das cidades costeiras levantinas, hesitando em punir as respectivas revoltas para defender os seus interesses económicos. Em contraste, Nabucodonosor prosseguia uma política de terra queimada de modo a expulsar os egípcios e a tornar a região sem utilidade para eles ${ }^{(22)}$. O avanço babilónico só terá tido uma pausa com a referida tentativa de invasão do Egipto, em 601, que se revelou um fracasso. Por outro lado, o apoio, sobretudo por via marítima, pres- 
tado pelo Egipto às cidades levantinas, permitiu a continuação da resistência ao invasor babilónico, nomeadamente no que respeita a Tiro, que só foi submetida em 572 depois de treze anos de cerco.

Esta resistência evidencia a manutenção da política egípcia através dos reinados de Psametek II (595-589) e Apriés (589-570), que a teriam complementado com incursões retaliatórias em 591 sobre as guarnições babilónicas e em 588 sobre os seus vassalos fenícios ${ }^{(23)}$. Desta última e aparentemente de outras incursões de Apriés dá conta Diodoro 68.1 (e também, embora de modo mais parco, Heródoto II.161), que refere o envio de forças terrestres e navais consideráveis contra Chipre e a Fenícia (que terá vencido numa grande batalha naval, conseguindo um grande saque), e a conquista de Sídon e a submissão pela ameaça de outras cidades fenícias. Contudo, o apoio aos aliados levantinos terá deixado muito a desejar quando eram exigidas intervenções terrestres, como foi o caso nos primeiros anos do reinado de Apriés no que respeita ao reino de Judá, em que o Egipto se mostrou incapaz de contrariar eficazmente o cerco e, em 586, a queda de Jerusalém às mãos de Nabucodonosor ${ }^{(24)}$.

Do reinado de Psametek II é também (591) uma incursão contra a Núbia (Heródoto II.161), a qual, para além de evidenciar uma nova faceta da política externa egípcia, deu origem aos conhecidíssimos graffiti deixados por mercenários gregos em Abu Simbel, nas pernas das estátuas colossais de Ramsés II. Esta continuidade do recurso aos mercenários gregos é complementada pelo recurso também a mercenários judeus na mesma expedição ${ }^{(25)}$. A razão para esta incursão seria preventiva ${ }^{(26)}$, dado que o rei de Kuch poderia estar a preparar um ataque ao Egipto, tentando aproveitar-se das circunstâncias (pressão babilónica) para ressuscitar a política imperialista dos seus antecessores da XXV dinastia. Psametek II terá por outro lado aproveitado a sua vitória, aparentemente esmagadora, para lançar uma campanha de propaganda contra os reis dessa dinastia, até então considerados como legítimos e a partir daí tratados como usurpadores. Essa campanha de cariz negativo, que procurou apagar dos monumentos tudo o que fazia lembrar tais soberanos, terá ainda sido complementada por uma propaganda de natureza positiva tendente a proclamar a grandeza da vitória alcançada por Psametek. 
Do reinado de Apriés é, por outro lado, além das intervenções visando a costa levantina e Chipre, outra orientação da política externa egípcia, desta vez contra os colonos gregos de Cirene e a favor do rei Adikran da Líbia. Esta orientação conduziu a um completo fracasso e esteve na origem da queda de Apriés e na subida ao poder de Amásis.

Da descrição de Heródoto (II. 161-3) ficamos a saber que a derrota das tropas egípcias enviadas (cerca de 571-570) contra os gregos de Cirene conduziu à revolta das mesmas e a uma tentativa de fazer face à situação através do envio do então general Amásis com a missão de apaziguar os revoltosos. A situação acabou por evoluir num sentido cada vez mais desfavorável a Apriés e com Amásis, sob sua instigação ou não, a ser aclamado rei pelos revoltosos, e de modo a não deixar outra alternativa ao primeiro que não fosse o recurso aos trinta mil mercenários gregos instalados a norte de Bubastis já desde o tempo de Psametek I. O combate entre as duas partes deu a vitória a Amásis que manteve Apriés prisioneiro durante algum tempo - porém, dada a insistência dos seus súbditos, acabou por o entregar para ser executado (Heródoto II. 169).

Em 567 Amásis terá decidido remover os mercenários gregos que Ihe foram opostos por Apriés para novas instalações em Mênfis, segundo Heródoto (II. 154) para o proteger dos próprios egípcios. Para além de uma interpretação ligada a uma invasão de Nabucodonosor ${ }^{(27)}$ (abaixo referida) ser possível, esta reinstalação tem sido compreendida como uma das medidas que Amásis tomou num contexto de reacção nacionalista contra a presença estrangeira no Egipto e da guerra civil (que teria sido originada por um conflito entre o exército regular egípcio e os mercenários gregos) que o opôs a Apriés. É neste enquadramento que James ${ }^{(28)}$ cita vários autores que descrevem Amásis como "o chefe de uma revolução nacionalista e anti-estrangeiros" ( $H$. R. Hall), "o chefe de um movimento anti-grego" (R. M. Cook), "o campeão dos interesses nacionais" (A. B. Lloyd), "o que enfrentou o problema dos gregos ... concentrando os estrangeiros na cidade de Naucratis" (N. Grimal) e refere que R. D. Sullivan descrevia Naucratis como "um local apropriado para confinar a colonização grega». Visões desta natureza não são contudo inteiramente compatíveis 
com a imagem que Heródoto nos deixou de Amásis, a de um amigo dos gregos. Embora a revolta de Amásis contra Apriés tenha conduzido a um afrontamento entre tropas egípcias (do lado de Amásis) e mercenários gregos (do lado de Apriés), a descrição dos acontecimentos em Heródoto (II.161-3 e II.169) não permite concluir por uma revolta nacionalista contra uma hipotética influência grega excessiva. A opção acima referida de Amásis por deslocar os gregos dos seus acampamentos para Mênfis "para o proteger dos egípcios" não deverá, por outro lado, em princípio, ser entendida no sentido oposto, o que não faria sentido, dados os acontecimentos relatados por Heródoto. A tradução deste passo em II.154 das Belles Lettres, diferente das versões inglesas consultadas, é disso elucidativa ao contrapor-Ihes: «... Amásis ... les prit comme gardes du corps de préférence à des Égyptiens".

O recurso de Apriés às tropas mercenárias gregas deverá assim ter sido meramente de oportunidade, dado serem provavelmente as tropas que the restavam ou as que estavam disponíveis. James ${ }^{(29)}$ refere ainda um argumento esgrimido a favor da hipotética oposição dos gregos a Amásis, uma estela (de Elefantina) do reinado deste em que se descreveria uma tentativa de retoma do poder por parte de Apriés (que difere portanto da versão de Heródoto acima referida da sua manutenção como prisioneiro) à frente de um grande contingente grego. Contudo, uma leitura correcta do documento, refere ainda James, conduz a identificar o grande contingente com o exército do rei Nabucodonosor. Restará a dúvida sobre o confinamento dos comerciantes gregos a Naucratis o qual, mais que a atribuição de um privilégio, poderá ter sido um modo de minimizar o que era sentido como um perigo.

Outra polémica, que é aliás a matéria principal em James ${ }^{(30)}$, é a do momento da fundação de Naucratis como estabelecimento grego que, segundo W. M. F. Petrie, o responsável pelas escavações de 1884-1885, teria tido lugar cerca de 650 a. C.. Baseando-se nomeadamente em escavações posteriores, em análises estratigráficas e numa profunda reavaliação da cronologia da cerâmica grega, James acaba por concluir não haver razão para alterar a data transmitida por Heródoto, ou seja, a fundação no período inicial do reinado de Amásis. Complementarmente, contudo, admite como provável a existência anterior no local de uma fábrica fenícia de escaravelhos, cujo mercado seria grego, e a que estaria associado um porto também fenício e uma aldeia indígena. A fábrica teria sido descontinuada cerca de 570 (ou seja, contemporaneamente ao estabelecimento dos gregos 
no local), provavelmente como consequência da alteração das relações internacionais (passagem de Tiro ao campo babilónico e eventual associação dos fenícios à invasão do Egipto por Nabucodonosor). Ainda a propósito da fábrica de escaravelhos, é significativa a existência, revelada por Gorton ${ }^{(31)}$ de outras fábricas fenícias produzindo imitações de produtos egípcios similares à de Naucratis (por exemplo, no Levante, em Cartago e na Sardenha).

Por outro lado, a presença grega no Egipto, mesmo que objecto de medidas de confinamento a Naucratis a partir de Amásis, poderá ter sido numerosa e geograficamente diversificada. Braun ${ }^{(32)}$, para além da referência a vestígios arqueológicos que provariam a presença de gregos nos postos militares mencionados por Heródoto, detalha-se toda uma série de elementos - nomeadamente lápides funerárias, graffiti, inscrições várias, fragmentos de autores gregos - que documentariam uma presença mais diversificada, não só de camponeses-hoplitas e comerciantes mas também de outros gregos indicando eventualmente estadias já de várias gerações.

Quer tenha sido fundada no reinado de Amásis quer anteriormente, Naucratis desenvolveu-se como centro comercial portuário, congregando gregos de variadas origens e assegurando as trocas entre uma multiplicidade de póleis helénicas e o Egipto. Ao que parece os gregos procuravam sobretudo cereais no Egipto, conforme se depreende de um fragmento de Baquílides, poeta da primeira metade do século $\mathrm{V}$ a. C. ${ }^{(33)}$, mas também papiro, linho, alúmen e artefactos vários, em que avultavam os marfins esculpidos e os bronzes finos. Uma fábrica de faianças operou durante o século VI em Naucratis, o que significaria provavelmente que também os seus produtos eram exportados para as cidades gregas. Em contrapartida os produtos importados pelos egípcios terão sido sobretudo os resultantes da recente especialização agrícola helénica, o vinho e o azeite, e a prata, que os gregos transportariam nomeadamente da Trácia e da Macedónia ${ }^{(34)}$.

Braun $^{(35)}$ dá grande relevância ao sincronismo entre o desenvolvimento de Naucratis (cujo início, diversamente de James, situa em 620) e uma "prodigiosa aceleração do comércio grego", em que se incluiu a fundação das mais importantes colónias milésias no mar Negro, a abertura por Olbia de uma parte do actual território da Ucrânia ao comércio grego, a fundação de Cirene, de Massalia e de Bizâncio. A referência por Heródoto (IV.152) a uma primeira viagem (por um navegador de Samos) a Tartessos, com um benefício comercial muito significativo, é igualmente localizável temporalmente neste período. 
Por outro lado, seria interessante, neste enquadramento, avaliar em que medida as razões relacionadas com as alterações da cronologia da cerâmica grega que conduziram James ${ }^{(36)}$ a optar por situar a fundação de Naucratis cerca de 570 viriam a afectar este declarado sincronismo.

Embora haja naturalmente dúvidas quanto à origem exacta dos fundadores da cidade, a existência comprovada de vários templos e das póleis que estiveram associadas à sua construção dá uma ideia da importância que o seu comércio revestiu para elas. Assim, o templo de maiores dimensões, o Hellenium, foi erigido pelas cidades jónias de Quios, Teos, Fócide e Clazómenas, pela eólida Mitilene e pelas dóricas Rodes, Cnido, Halicarnasso e Fasélis. As cidades com interesses comerciais maiores construíram templos próprios: Mileto o templo de Apolo, Samos o templo de Hera e Egina o templo de Zeus. Existiam também um templo dos Dioscuros e um templo de Afrodite. Por outro lado, embora não se possa considerar Naucratis como uma pólis, dado a submissão à suserania egípcia, a cidade era gerida por representantes das cidades fundadoras e também por magistrados eleitos localmente.

O estatuto político-económico-administrativo de Naucratis tem sido objecto de discussão por vários autores, sendo de destacar a caracterização que dela tem sido feita como porto de comércio ${ }^{(37)}$ pela que podemos designar "escola de Polanyi». A importância deste conceito para a História Antiga está em que ele permite caracterizar uma situação de troca que não se faz, pelo menos inteiramente, de acordo com as regras de mercado (ou partindo de uma mentalidade de mercado). No caso concreto de Naucratis estariam face a face os comerciantes gregos, agindo numa lógica de obtenção de lucro, e as entidades públicas egípcias, com a sua lógica de economia redistributiva administrada e agindo sobretudo como transportadores de bens (lógica determinada pela concepção faraónica, extensível aliás aos impérios mesopotâmicos, de que as correspondentes importações consubstanciavam tributo pago pelos povos submetidos) ${ }^{(38)}$.

A ameaça babilónica esbateu-se no decurso do reinado de Amásis, com a morte em 562 a. C. de Nabucodonosor e, sobretudo, com o surgimento em cena da Pérsia de Ciro II, unificador do poder 
medo-persa. Em breve os diferentes estados estavam a procurar formas de apoio mútuo para se defenderem da ameaça da nova potência. De acordo com Heródoto (1.77), Amásis estabeleceu um tratado de aliança com Creso, rei da Lídia, o qual, por outro lado, firmou um acordo semelhante com Babilónia e Esparta. Em breve, contudo, tanto a Lídia (546) como o Império Neobabilónio (539) cairiam em poder dos Persas. As cidades fenícias, antes potencialmente inimigas dos Babilónicos e expectantes do auxílio egípcio, receberam de bom grado os novos senhores e passaram a constituir um obstáculo considerável para os navios do país do Nilo. Amásis ainda estabeleceu uma aliança com o tirano de Samos, Policrates (535-522), que não parece no entanto ter sido duradoura, mas o destino do Egipto foi adiado pela morte de Ciro (530). Contudo, o seu filho Cambises, após ter posto a casa em ordem na sequência da sucessão, atacou em 525 (Heródoto III.4-15), tendo o exército egípcio sofrido elevadas perdas na batalha que the opôs e retirado em desordem para Mênfis, cidade que acabou por ser tomada sem grande dificuldade. Psametek III, que havia sucedido a seu pai Amásis alguns meses antes, foi capturado com a sua família, tendo na altura sido poupado, mas posteriormente executado quando foi descoberta uma conspiração que tramava contra Cambises.

A actividade mediterrânica da força naval egípcia no reinado de Amásis parece ter-se mantido com algum vigor e ter mesmo resultado na conquista de Chipre (Heródoto II.182). A actividade da frota de Amásis ${ }^{(39)}$ terá levado o Egipto a estabelecer relações comerciais e diplomáticas com regiões que antes se encontravam fora da esfera tradicional de interesses do país. Disso constituiriam provas os tratados acima referidos e as relações de amizade com os gregos que Heródoto tanto refere e que terá levado Amásis a conceder um grande número de donativos e outros favores a templos e santuários helénicos. Não deixa por isso de ser mordazmente irónico que um faraó que tanto fez pelo alargamento dos horizontes de um país essencialmente tradicionalista e arcaizante tenha sido vítima, já depois de morto e por parte dos conquistadores do seu país, de práticas altamente vexatórias e sacrílegas sobre o seu cadáver (Heródoto, III.16). 


\section{Notas}

(1) JAMES 1982, p. 700

(2) ELAT 1978, pp. 20-1

(3) ELAT 1978, pp. 21-4

(4) ELAT 1978, pp. 24-6 e 30-1

(5) SPALINGER 1974, pp. 323-5

(6) Segundo Diodoro (I 66.7-12), Psametek, senhor das regiões costeiras, havia estabelecido relações comerciais com povos estrangeiros, sobretudo gregos e fenicios. Ainda segundo Diodoro, a guerra com os outros príncipes do Delta deveu-se à inveja que estes sentiram pelo enriquecimento de Psametek, tendo então o futuro faraó mandado vir mercenários da Cária e da Jónia.

(7) JAMES 1982, pp. 711-12

(8) JAMES 1982, pp. 713-714

(9) Heródoto (II.30) diz-nos que, além dos dois acampamentos referidos, existiam, no reino de Psametek, postos militares em Dafnas, também no ramo pelusíaco do Nilo, em Elefantina, próximo da fronteira com a Núbia, e em Márea, a oeste da actual Alexandria e visando controlar a estrada da Líbia. Heródoto refere guarnições egípcias para estes postos mas a existência de também tropas gregas nestes locais não pode ser excluída.

(10) Ibidem.

(11) Gyges, um dos primeiros tiranos que a História regista, terá procurado junto de Assurbanípal, sem sucesso, auxílio contra a ameaça ciméria. De acordo com SPALINGER 1978 , p. 405, desembaraçou-se sozinho dessa ameaça e tentou posteriormente uma aproximação a Psametek, tendo-Ihe enviado (entre 662 e 658) tropas gregas do litoral da Ásia Menor por ele controladas. Não são apresentadas razões claras para esta aproximação, não sendo claro se estas tropas coincidem com os piratas referidos por Heródoto ou se se trata de um outro contingente. Gyges haveria de perecer em 644, durante um novo ataque dos cimérios a Sardis, os quais terão mais tarde sido vencidos e afastados da Ásia Menor pelos Citas (SPALINGER 1978, p. 405). Terá sido, portanto, posteriormente a esta data que este novo invasor terá ameaçado o Egipto e sido afastado pela acção conciliadora de Psametek que para o efeito os terá cumulado de presentes (Heródoto I.105).

(12) CORRAL 2002, p. 77, citando REDFORD 1992.

(13) CORRAL 2002, p. 77. De acordo com um documento egípcio, uma estela datada de 612 , os reis fenícios pagavam tributo a um representante do faraó no território levantino. Por outro lado, muitas das provas da presença egípcia na área derivam de escavações sem datação precisa, as quais, segundo CORRAL 2002, pp. 77-81, tanto podem ser interpretadas como resultantes de controlo político directo como de simples trocas comerciais. De acordo com o mesmo autor, REDFORD 1992 e SPALINGER 1977 defendem a primeira hipótese enquanto KATZENSTEIN 1997 e um outro autor (Asher) se inclinam para a segunda. VANDERHOOFT 1999 hesitaria entre as duas.

(14) ELAT 1978, pp. 23-5 apresenta uma discussão, não conclusiva, sobre a origem dos cavalos apreendidos por Assarhadão, entre a sua criação na Núbia ou provenientes de importações asiáticas, provavelmente de uma área situada nas montanhas da Capadócia. Independentemente da origem, contudo, não teria sido certamente fácil reconstituir num curto espaço de tempo uma força com um grande número de cavalos.

(15) JAMES 1982, p. 716. 
(16) De facto existem ainda referências em Heródoto (II.159) a vitórias de Necau em Magdolos (ou Migdol) e Cadytis, a primeira eventualmente confundida com a vitória em Megiddo sobre o rei de Judá, mas cuja cronologia e localização, e portanto o respectivo significado, não são objecto de concordância pelos académicos.

(17) JAMES 1982, p. 717.

(18) Segundo Heródoto (IV.42) esta expedição teria sido bem sucedida e os navios lançados através do Oceano índico teriam de facto contornado África e, entrando pelas Colunas de Hércules, atingido o Mediterrâneo e regressado ao Egipto. A referência a triremes por parte de Heródoto (II.159) poderá ser anacrónica e ter-se tratado de facto de outro tipo de navios.

(19) BRAUN 1982, p. 49.

(20) CORRAL 2002, pp. 80-1. Tanto a iniciativa de efectuar a circum-navegação de África como a de construir o canal para efeitos comerciais parecem ultrapassar em muito o que é normal esperar de um soberano egípcio, mesmo nesta época já avançada, o que tem levado a especulações de que as mesmas tenham de facto tido lugar mais tardiamente sob o domínio persa (por exemplo, no caso do canal, Heródoto teria interpretado erradamente o início da construção do canal, que teria ocorrido também já no período persa).

(21) CORRAL 2002, pp. 79-85.

(22) Diversamente também dos assírios, que tinham uma política de deportação cruzada de populações, os babilónios limitavam-se a deportar massivamente as populações conquistadas para a Babilónia. Isto conduzia a que não houvesse trocas comerciais entre os territórios conquistados e o país conquistador, tendo o fluxo de produtos e de homens um único sentido sob a forma de tributo. Só no final do reinado de Nabucodonosor, décadas mais tarde, haveria indícios de "comércio bilateral", com fornecimento portanto de produtos babilónicos, o que continuaria a verificar-se nos reinados dos seus sucessores e prosseguindo sob o período persa.

(23) CULICAN 1982, p. 470.

(24) JAMES 1982, pp. 718-719.

(25) BRAUN 1982, p. 51, que cita uma tradução para grego da Bíblia da época helenística. Por outro lado, JAMES 1982, p. 718, procura explicar a presença dos mercenários judeus pela existência de um tratado com o reino de Judá que teria conduzido ao fornecimento de tal contingente. É já difícil compreender esta incursão de Psametek II e ainda mais o apoio judeu, num momento em que a ameaça babilónica estava em vias de se concretizar sobre o próprio reino de Judá com as consequências já referidas.

(26) SAUNERON e YOYOTTE 1952, pp. 190-199.

(27) Esta hipotética invasão de Nabucodonosor, que teria tido lugar em 571, está envolta em polémica, como resulta de JAMES 1982, p. 719, que se apoia em SPALINGER 1977. Isto porque não há documentos contemporâneos, com excepção de um texto incompleto babilónico que a situa em 568, que a atestem, resultando o seu conhecimento apenas de tradição mais tardia. Segundo essa tradição a intervenção de Nabucodonosor teria conduzido à morte de Apriés e à sua substituição por Amásis. James, contudo, não parece dar grande crédito a tal hipótese nem a uma sugestão no sentido de Amásis ter, logo após ter acedido ao poder, efectuado uma incursão na Ásia que teria levado a um choque com Nabucodonosor.

(28) JAMES 2003, p. 247, nota 63.

(29) JAMES 2003, p. 247 
(30) JAMES 2003.

(31) Citado em JAMES 2003, p. 256.

(32) BRAUN 1982, pp. 43-52.

(33) BRAUN 1982, p. 39.

(34) BRAUN 1982, pp. 39-40.

(35) BRAUN 1982, pp. 38-39.

(36) JAMES 2003.

(37) Port of trade ou port de commerce, respectivamente em inglês e francês.

(38) Ver MÖLLER 2000 e MAUCOURANT; GRASLIN 2005.

(39) JAMES 1982, p. 725.

\section{Bibliografia consultada}

BRAUN T. F. R. G., "The Greeks in Egypt", The Cambridge Ancient History, vol. 3, part 3, Cambridge: University Press, 1982, pp. 32-56

CASSIN Elena, BOTTÉRO Jean, VERCOUTTER Jean (eds.), Los Imperios del Antiguo Oriente: III. La primera mitad del primer milenio, Madrid, 1984 (1965)

CORRAL Martin Alonso, Ezekiel's Oracles Against Tyre: Historical Reality and Motivations, Roma: Biblical Institute, 2002, pp. 77-85

CULICAN William, «Phoenicia and Phoenician Colonization", The Cambridge Ancient History, vol. 3, part 2, Cambridge: University Press, 1982, pp. 461-473

ELAT Moshe, "The Economic Relations of the Neo-Assyrian Empire with Egypt", Journal of the American Oriental Society, 98.1, 1978, pp. 20-34

JAMES Peter, "Naukratis Revisited", Hyperboreus: Studia classica, 9:2, 2003, pp. 235-264

JAMES T. G. H., "Egypt: the Twenty-fifth and Twenty-sixth Dynasties", The Cambridge Ancient History, vol. 3, part 2, Cambridge: University Press, 1982, pp. 677-747

KIENITZ Friedrich Karl, "El Renacimiento Saita", em Elena Cassin, Jean Bottéro e Jean Vercoutter (eds.), 1984, pp. 231-254

MAUCOURANT Jérôme, GRASLIN Laëtitia, "Le port de commerce: un concept en débat", Topoi, Orient Occident, 12-13, 2005, pp. 216-257

MÖLLER Astrid. Naukratis: Trade in Archaic Greece, Oxford: Oxford University Press, 2000 (capitulo III: "Egypt under the Saite Dynasty")

SAUNERON Serge, YOYOTTE Jean, "La campagne nubienne de Psammétique II et sa signification historique", BIFAO, 50, 1952, pp. 157-207

SPALINGER Anthony, "Assurbanipal and Egypt: a source study", Journal of the American Oriental Society, 94, pp. 316-28, 1974

SPALINGER Anthony, "The Date of the Death of Gyges and its Historical Implications", Journal of the American Oriental Society, vol. 98, 4, 1978, pp. 400-409 
FILIPE NEVES DO CARMO

\section{Outra bibliografia}

GORTON A. F., Egyptian and Egyptianising Scarabs, Oxford, 1996

KATZENSTEIN H. J., The History of Tyre: From the Beginning of the Second Millenium B.C.E. until the Fall of the Neo-Babylonian Empire in 539 B.C.E., Ben-Gurion University, 1997

REDFORD Donald B., Egypt, Canaan, and Israel in Ancient Times, Princeton, 1992

SPALINGER Anthony, "Egypt and Babylonia: A Survey (c. 620-550 B. C.)", em Studien zur altagyptischen Kultur, 5, 1977, pp. 221-244

VANDERHOOFT David S., The Neo-Babylonian Empire and Babylon in the Latter Prophets, Atlanta: Scholars Press, 1999 